\title{
Protein metabolism in skeletal muscle: the effect of feeding and fasting on muscle RNA, free amino acids and plasma insulin concentrations
}

\author{
By D. J. MILLWARD, D. O. NNANYELUGO, W. P. T. JAMES \\ AND P. J. GARLICK \\ Clinical Nutrition and Metabolism Unit, Hospital for Tropical Diseases, \\ St Pancras Way, London NWI 2 PE
}

(Received г3 August I973 - Accepted I8 October 1973)

\begin{abstract}
I. This study set out to measure the sensitivity of muscle RNA content to food intake and food restriction, and to relate this to plasma insulin and intracellular amino acid concentrations.

2. Young rats were trained for 2 weeks to consume their daily food ration in a single $4 \mathrm{~h}$ period. After this time they had resumed normal growth. The rats were killed at intervals over $24 \mathrm{~h}$ and subsequently at daily intervals. One group was given a protein-free meal in place of the stock diet and a similar procedure was followed. Measurements were made of plasma insulin, concentration of nucleic acids and protein in liver, heart and skeletal muscle, and free amino acids in the gastrocnemius muscle.

3. Following the meal there was a fivefold increase in plasma insulin, which was accompanied by small increases in the concentrations of the intracellular amino acids in muscle. In all the tissues, after feeding, the RNA:DNA ratio increased by (\%) 20, 19 and 12 in liver, skeletal and heart muscle respectively.

4. During the fasting period the plasma insulin decreased, and this decrease was accompanied by rapid losses of RNA from liver, muscle and heart at similar rates. There were increases in the concentrations of the essential amino acids, especially methionine and the branched-chain amino acids, but decreases, in general, in those of the non-essential amino acids. When the protein-free meal was given, there was a small increase in the plasma insulin, but the RNA was lost from the three tissues at the same rate as in the starved rats. There was, however, a transient fall in the concentrations of the essential amino acids.

5. The rapid changes in muscle RNA concentrations following food intake demonstrate that the minimum turnover rate of RNA in this tissue must be considerably faster than has been previously reported, and must be similar to that in liver. There is a direct correlation between tissue RNA concentration and that of plasma insulin, but little correlation between tissue RNA concentration and that of the intracellular essential amino acids.
\end{abstract}

The rate of synthesis of skeletal muscle protein is very sensitive to dietary intake (Waterlow \& Stephen, I968). Starvation, in particular, causes an immediate decrease in the rate of synthesis, resulting in a net loss of muscle protein (Millward, 1970b). These changes in the metabolism of skeletal muscle protein are very important to the whole organism because of the large proportion of metabolically active tissue accounted for by skeletal muscle (Young, I970; Millward \& Garlick, 1972).

Changes in the rate of muscle protein"synthesis have been shown to be associated with changes in the RNA content of this tissue (Millward, Garlick, James, Nnanyelugo \& Ryatt, 1973). In addition the amounts of both insulin and free amino acid in muscle have been shown to affect the aggregation of subunits into active polyribosomes and the subsequent rate of protein synthesis (Morgan, Jefferson, Wolpert \& Rannels, I97I). The work described in this paper was done to determine 
Table I. Composition (g) of protein-free diet given to rats in Expt 4

$\begin{array}{lr}\text { Salt mix* } & 50 \\ \text { Vitamin B mix* } & \text { I I } \\ \text { Fat-soluble vitamins* } & \text { I } \\ \text { Arachis oil } & 50 \\ \text { Solkafloc } \dagger & \text { I00 } \\ \text { Dextrinized maize starch } & 300 \\ \text { Maize starch } & 590\end{array}$

* Composition as described by Payne \& Stewart (I 972).

$\uparrow$ A commercial cellulose preparation.

the immediate effect of feeding both a stock diet and a protein-free meal, and of starvation on tissue RNA levels, muscle free amino acid and plasma insulin concentrations. In order to follow precisely the time sequence of the changes, rats were trained to eat their daily ration in a single $4 \mathrm{~h}$ period. A preliminary account of some of these results has been presented previously (Millward \& Garlick, 1972).

\section{EXPERIMENTAL}

Four experiments were done. In Expt I, forty-two male Wistar rats, each weighing roo g, were housed in groups of three and allowed access to food only between 09.00 and I3.00 hours. Adapting the convention of Watanabe, Potter \& Pitot (I968), this dietary regimen is called a $4+20$ schedule. The food was standard cubed diet (Oxoid, Southwark Bridge Rd, London SE I) containing $200 \mathrm{~g}$ crude protein $/ \mathrm{kg}$. After 2 weeks of this dietary regimen the rats were killed in groups of six immediately before a meal period $(t=o \mathrm{~h})$ and at $6,12,18,24,48$ and $72 \mathrm{~h}$ after the commencement of feeding. No food was given after the initial meal. In Expts 2 and 3 an identical procedure was followed except that thirty-six rats were used in each experiment, and groups were killed at $0,8,16,24,4^{8}$ and $72 \mathrm{~h}$ after the beginning of the last meal period. In Expt 4 the meal was changed to an approximately isoenergetic protein-free mixture (Table I) after which the rats were killed in the manner described for Expts 2 and 3 .

The rats were killed by cervical dislocation and blood was taken immediately by cardiac puncture. The liver, heart and gastrocnemius muscles were rapidly excised, weighed and frozen in solid $\mathrm{CO}_{2}$. Tissues were stored at $-20^{\circ}$ until required for analysis. The stomach was removed, weighed and discarded.

Not all measurements were made in each of the experiments. In Expt $\mathrm{I}$, plasma insulin content and stomach weight were measured; in Expt 2, RNA, DNA and protein content of liver, heart and gastrocnemius muscle, and the sarcoplasmic- and myofibrillar-protein content of gastrocnemius muscle were measured, and in Expt 3 only muscle free amino acid concentrations were measured. In Expt 4 , RNA, DNA and protein content of liver, heart and gastrocnemius muscle were measured, also plasma insulin and muscle free amino acid contents.

Plasma insulin was determined by the radioimmunoassay of Hales \& Randle ( 1963 ), using the kit supplied by the Radiochemical Centre, Amersham, Bucks.

Nucleic acids were measured by the method of Munro \& Fleck (1969) except that 
DNA was extracted with $0.8 \mathrm{M}$-perchloric acid at $70^{\circ}$ and determined colorimetrically by the diphenylamine method as modified by Giles \& Meyers (1965).

Protein was measured by the method described by Lowry, Rosebrough, Farr \& Randall (I95I).

Muscle free amino acids were measured by ion-exchange chromatography using a Locarte amino acid analyser with a $500 \mathrm{~mm}$ column and lithium citrate buffers as described by Benson, Gordon \& Patterson (r967). The gastrocnemius muscle was homogenized in ice-cold sulphosalicylic acid and a standard solution of norleucine was added. After washing the precipitate, the washings and original supernatant were combined, the volume noted, and a portion analysed. The amounts of each amino acid were calculated by comparing the respective peak areas with that of the norleucine standard. In the $t=0$ group, samples from pairs of rats were pooled so that three complete analyses were performed, but for subsequent groups all the samples were pooled.

Sarcoplasmic and myofibrillar proteins were extracted as previously described (Millward, r970a) using $0.03 \mathrm{M}$-phosphate buffer, $\mathrm{pH} 7.4$ and $0.3 \mathrm{M}-\mathrm{NaOH}$.

The statistical significance of the results was tested by Student's $t$ test.

\section{RESULTS}

\section{The effects of feeding the stock diet and subsequent fasting}

Growth rates. Fig. I shows that the immediate effects of the $4+20$ schedule were a cessation of growth and loss of weight. However, after $2 \mathrm{~d}$ the animals resumed slow growth and after $5 \mathrm{~d}$ the growth rate was comparable with that of rats fed ad lib. All weighings were made immediately before feeding as there were considerable variations in body-weight throughout the cycle. This is demonstrated in Fig. 2 which shows the changes found in stomach weights. The rats responded to the decreased feeding time by gorging and thus filling the stomach with sufficient food for the subsequent $20 \mathrm{~h}$ fast. Similar results were obtained by Watanabe et al. (1968) with rats given an $8+40$ feeding schedule.

Plasma insulin. The changes in stomach weight were paralleled by changes in the plasma immuno-reactive insulin shown in Fig. 3. After feeding, the plasma level increased considerably so that at $8 \mathrm{~h}$, i.e. $4 \mathrm{~h}$ after the cessation of feeding, the level was 5 times the initial level but after a further $8 \mathrm{~h}$ it had returned almost to the initial level. At the end of the second day, in the absence of food, the level was $65 \%$ of the initial level, and this decreased further to $46 \%$ ( $\left.\mathrm{I}_{4} \mu \mathrm{units} / \mathrm{ml}\right)$ of the initial level after $3 \mathrm{~d}$.

Composition of tissues. Table 2 shows the composition of the gastocnemius, heart and liver muscles at the beginning of Expts 2 and 4, i.e. after a $20 \mathrm{~h}$ fast. While there are small differences between the values obtained for the two groups, these differences reflect normal variation and are not significant. The values are similar to those found by many other workers but nevertheless they deserve some comment. The fractional rates of synthesis of liver, heart and skeletal muscle are $(\% / d) 60,20$ and ro respectively (Millward \& Garlick, 1972) and it is reasonable to expect these rates to be reflected 


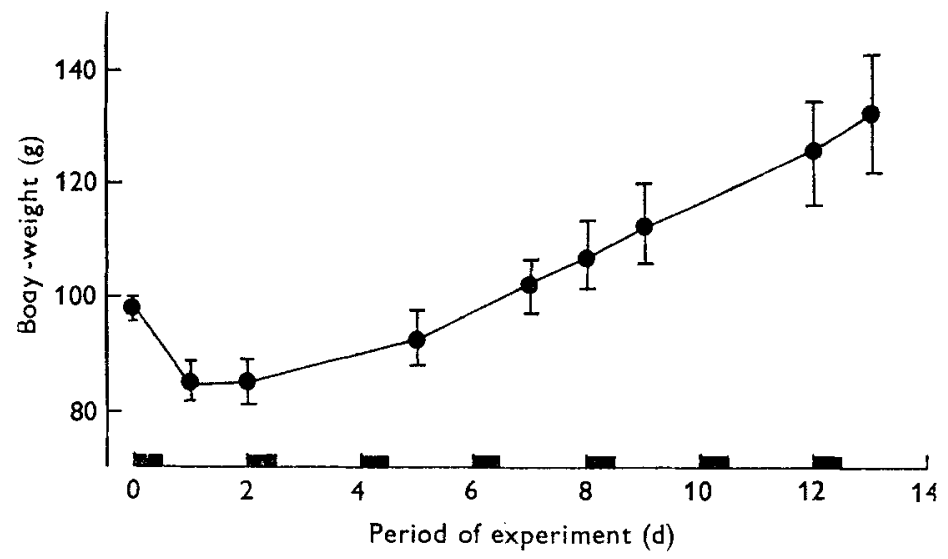

Fig. x. Effect of $4+20$ feeding schedule (Watanabe, Potter \& Pitot, 1968) on growth of rats (mean values and standard deviations (vertical bars)). The feeding times are indicated by the hatched areas.

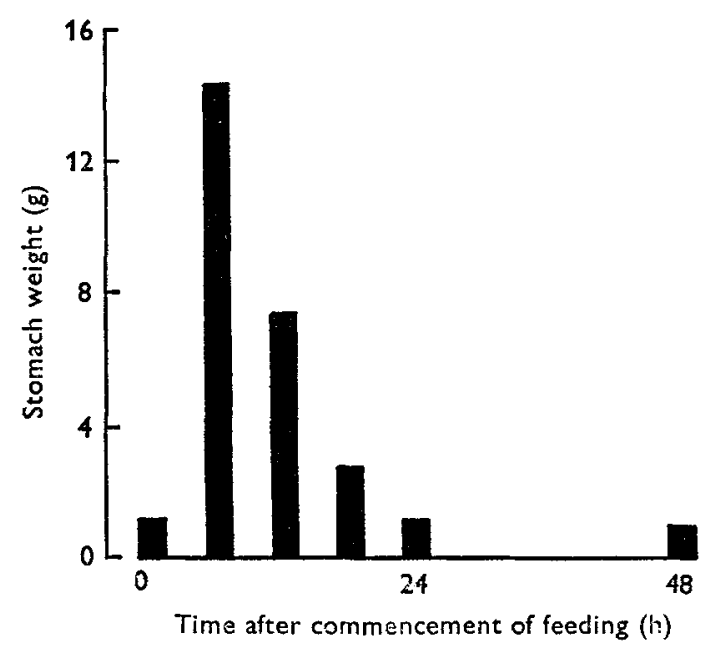

Fig. 2. Effect of $4+20$ feeding schedule (Watanabe, Potter $\&$ Pitot, r968) and starvation for I $\mathrm{d}$ on rat stomach weights.

in the tissue RNA concentrations; Table 2 shows that this is approximately true for RNA concentrations and RNA: protein ratios. It should be noted, however, that the DNA concentration in heart muscle is such that the RNA:DNA ratio in this tissue is less than those of liver and skeletal muscle; this is because some heart nuclei are polyploid. The RNA:DNA ratio, in this situation, is not a good indicator of the cellular RNA content.

Protein content. There were no significant changes in weights in the heart or gastrocnemius muscle during either the feeding period or subsequent fasting period. In contrast, the liver weight varied considerably as previously described by Watanabe et al. (1968), increasing after feeding and decreasing during fasting. Fig. 4 shows that these changes in liver weight were paralleled by changes in the cellular protein content expressed as the protein:DNA ratio. In heart and skeletal muscle the variability in 


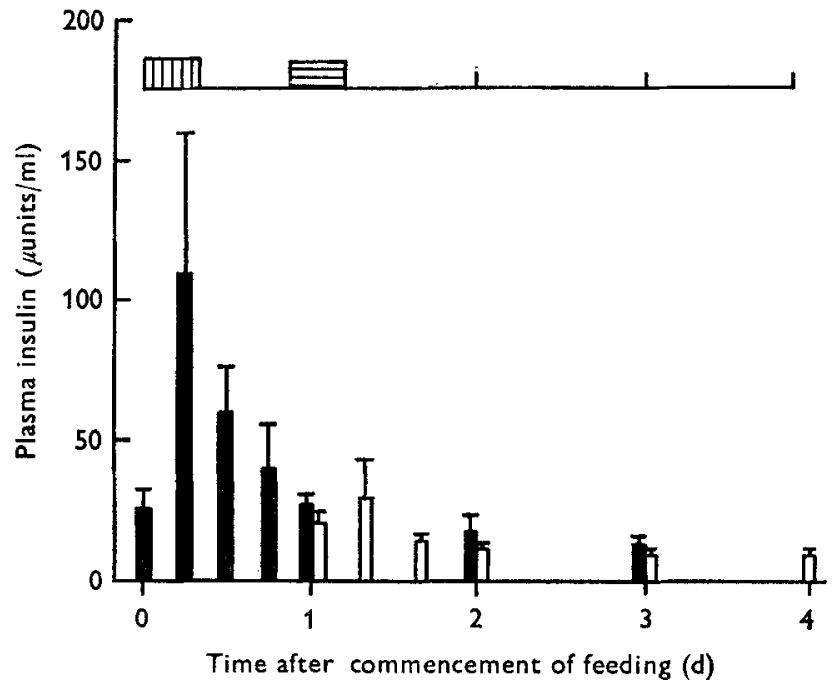

Fig. 3. Effect of $4+20$ feeding schedule (Watanabe, Potter $\&$ Pitot, I968) in Expts I and 4 on plasma insulin concentrations. $\mathbf{1}$, (Expt I) measurements made on rats given the stock diet at the beginning of the Ist day and subsequently fasted; $\square$, (Expt 4) measurements made on rats given the protein-free diet at the beginning of the 2 nd day and subsequently fasted. Food intake is shown on the separate axis. II, stock diet feeding time; $⿴$, protein-free diet feeding time. Vertical bars represent standard deviations.

Table 2. Composition of the gastrocnemius, heart and liver $(\mathrm{mg} / \mathrm{g})$ of rats at the beginning of experimental periods 2 and 4

(Mean values and standard deviations for six rats in each group)

\begin{tabular}{|c|c|c|c|c|c|c|c|c|c|c|c|c|c|}
\hline \multirow[b]{2}{*}{ Tissue } & \multirow[b]{2}{*}{ Expt } & \multicolumn{2}{|c|}{ DNA } & \multicolumn{2}{|c|}{ RNA } & \multicolumn{2}{|c|}{ Protein } & \multicolumn{2}{|c|}{$\begin{array}{l}\text { RNA: } \\
\text { DNA }\end{array}$} & \multicolumn{2}{|c|}{$\begin{array}{l}\text { RNA: } \\
\text { Protein } \\
\left(\times 10^{3}\right)\end{array}$} & \multicolumn{2}{|c|}{$\begin{array}{c}\text { Protein: } \\
\text { DNA }\end{array}$} \\
\hline & & Mean & SD & Mean & SD & Mean & SD & Mean & SD & Mean & $\mathrm{SD}$ & Mean & SD \\
\hline Gastrocnemius & $\begin{array}{l}2 \\
4\end{array}$ & $\begin{array}{l}0.63 \\
0.67\end{array}$ & $\begin{array}{l}0.05 \\
0.10\end{array}$ & $\begin{array}{l}x \cdot 28 \\
x \cdot 42\end{array}$ & $\begin{array}{l}0.16 \\
0.21\end{array}$ & $\begin{array}{l}164 \\
\text { I } 82\end{array}$ & $\begin{array}{r}21 \\
8\end{array}$ & $\begin{array}{l}1 \cdot 99 \\
2 \cdot 16\end{array}$ & $\begin{array}{l}0.30 \\
0.23\end{array}$ & $\begin{array}{l}7 \cdot 8 \\
7 \cdot 8\end{array}$ & $\begin{array}{l}0.8 \\
0.7\end{array}$ & $\begin{array}{l}260 \\
271\end{array}$ & $\begin{array}{l}32 \\
35\end{array}$ \\
\hline Heart & $\begin{array}{l}2 \\
4\end{array}$ & $\begin{array}{l}2 \cdot 52 \\
2 \cdot 11\end{array}$ & $\begin{array}{l}0.17 \\
0.14\end{array}$ & $\begin{array}{l}2 \cdot 34 \\
2 \cdot 46\end{array}$ & $\begin{array}{l}0.16 \\
0.15\end{array}$ & $\begin{array}{l}160 \\
178\end{array}$ & $\begin{array}{l}18 \\
10\end{array}$ & $\begin{array}{l}0.93 \\
I \cdot 16\end{array}$ & $\begin{array}{l}0.10 \\
0.14\end{array}$ & $\begin{array}{l}15.6 \\
13.8\end{array}$ & $\begin{array}{l}I \cdot 3 \\
I \cdot 0\end{array}$ & $\begin{array}{l}64 \\
85\end{array}$ & $\begin{array}{r}10 \\
8\end{array}$ \\
\hline Liver & $\begin{array}{l}2 \\
4\end{array}$ & $\begin{array}{l}2.88 \\
3.09\end{array}$ & $\begin{array}{l}0.12 \\
0.3^{8}\end{array}$ & $\begin{array}{l}11 \cdot 35 \\
13 \cdot 17\end{array}$ & $\begin{array}{l}0.30 \\
x \cdot 80\end{array}$ & $\begin{array}{l}207 \\
184\end{array}$ & $\begin{array}{l}20 \\
21\end{array}$ & $\begin{array}{l}3.95 \\
4.28\end{array}$ & $\begin{array}{l}0.20 \\
0.21\end{array}$ & $\begin{array}{l}54 \cdot 8 \\
71 \cdot 6\end{array}$ & $\begin{array}{r}6 \cdot 2 \\
15 \cdot 2\end{array}$ & $\begin{array}{l}72 \\
60\end{array}$ & $\begin{array}{r}9 \\
11\end{array}$ \\
\hline
\end{tabular}

this ratio between individual rats within groups was greater than that between groups, so that there was no significant change in the protein:DNA throughout the $3 \mathrm{~d}$ period ( $P>0.05$ for all groups, compared with the initial value). The amount of total protein in the gastrocnemius muscle, also the amounts of the two intracellular protein fractions, the sarcoplasmic and myofibrillar protein, were also measured. The sarcoplasmic-: myofibrillar-protein ratio was unchanged throughout the feeding and fasting priod.

$R N A: D N A$ ratio. Previous workers have shown that in the liver the RNA:DNA ratio shows rhythmic variations in meal-fed rats (Potter, Baril, Watanabe $\&$ Whittle, I968) and that RNA is very rapidly lost in starvation (Enwonwu \& Munro, I970). 


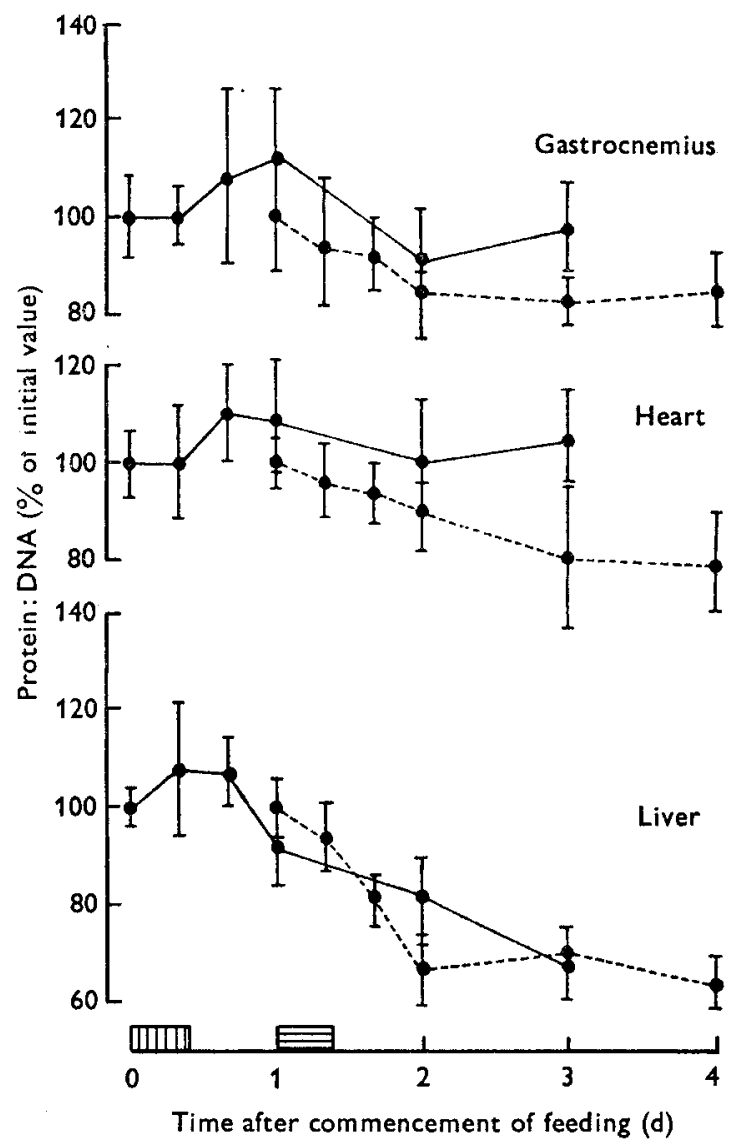

Fig. 4. Effect of $4+20$ feeding schedule (Watanabe, Potter $\&$ Pitot, 1968) in Expts 2 and 4 on tissue protein:DNA ratios. -, (Expt 2) measurements made on rats given the stock diet at the beginning of the Ist day and subsequently fasted;---, (Expt 4) measurements made on rats given the protein-free diet at the beginning of the and day and subsequently fasted

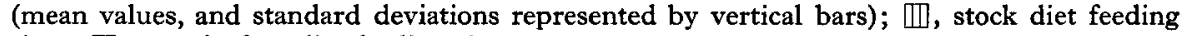
time; $⿴ 囗$ protein-free diet feeding time.

These findings were confirmed in the present experiments (see Fig. 5). The increase in RNA:DNA ratio following feeding, and the rapid decrease after starvation, seen in the liver were, however, also observed in the other two tissues. In the gastrocnemius muscle the response to feeding was delayed as there was no change at $8 \mathrm{~h}$. Nevertheless, at $16 \mathrm{~h}$ the RNA:DNA ratio had increased to $1 \mathrm{I} 8 \%$ of the initial value $(0.0025>$ $P>0.005)$ and the rate of decrease after this time was as rapid as that observed in the liver. In the heart the changes were less pronounced; there was a $12 \%$ increase at r6 h $(0.05>P>0.025)$. The subsequent loss of RNA was almost as rapid as in the other tissues since 17 and $9 \%$ were lost in the second and third days. These changes in the RNA:DNA ratios can be considered to represent changes in the total tissue RNA, as the DNA content of the tissues did not alter in the experimental period.

$R N A$ :protein ratio. In Fig. 6 the changes in the RNA:protein ratios are shown. 
Vol. 32
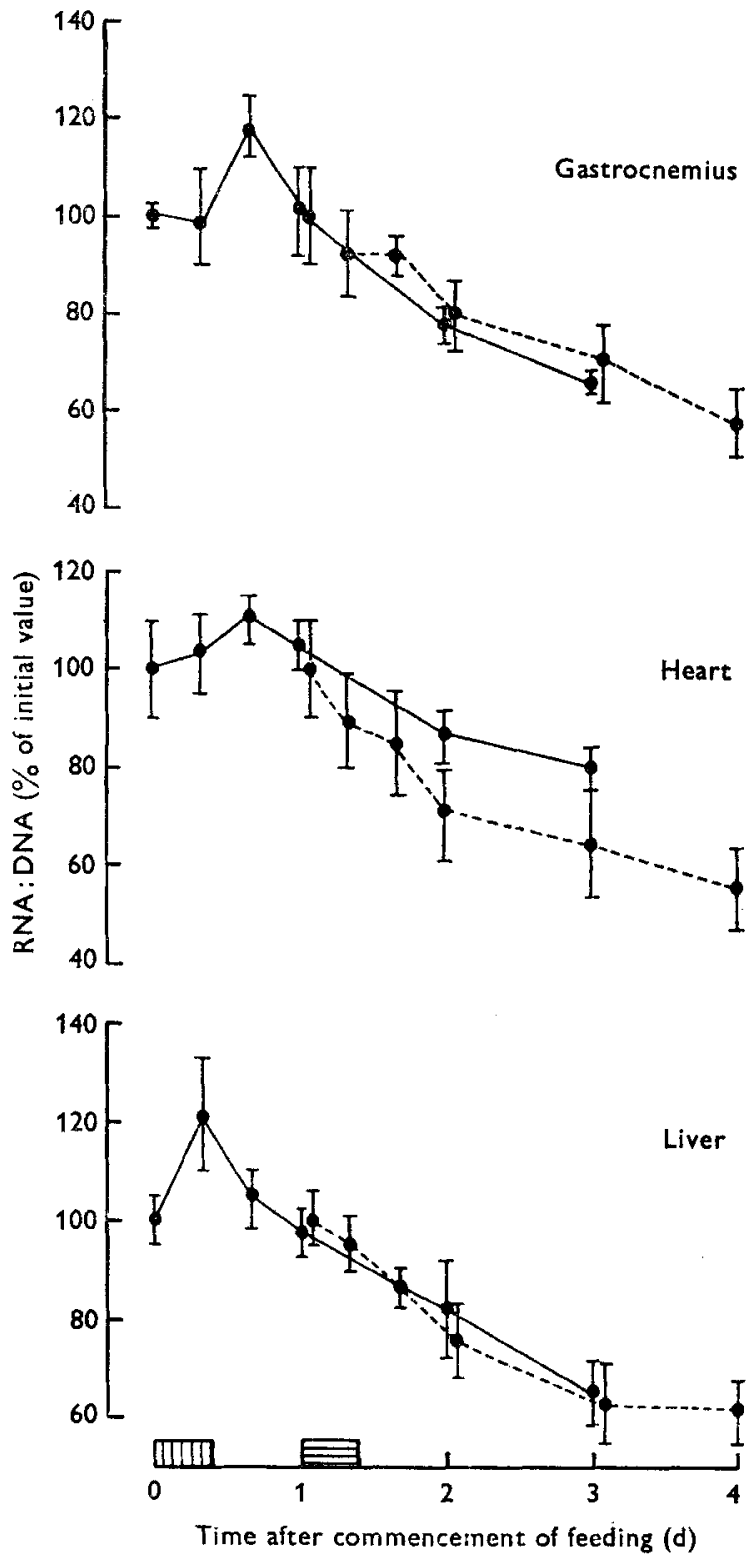

Fig. 5. Effect of $4+20$ feeding schedule (Watanabe, Potter $\&$ Pitot, 1968) in Expts 2 and 4 on tissue RNA:DNA ratios. - Measurements made on rats given stock diet at beginning of the Ist day and subsequently fasted; ---, measurements made on rats given the proteinfree diet at beginning of the 2nd day and subsequently fasted (mean values, and standard

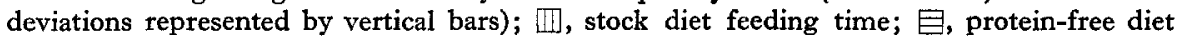
feeding time. 


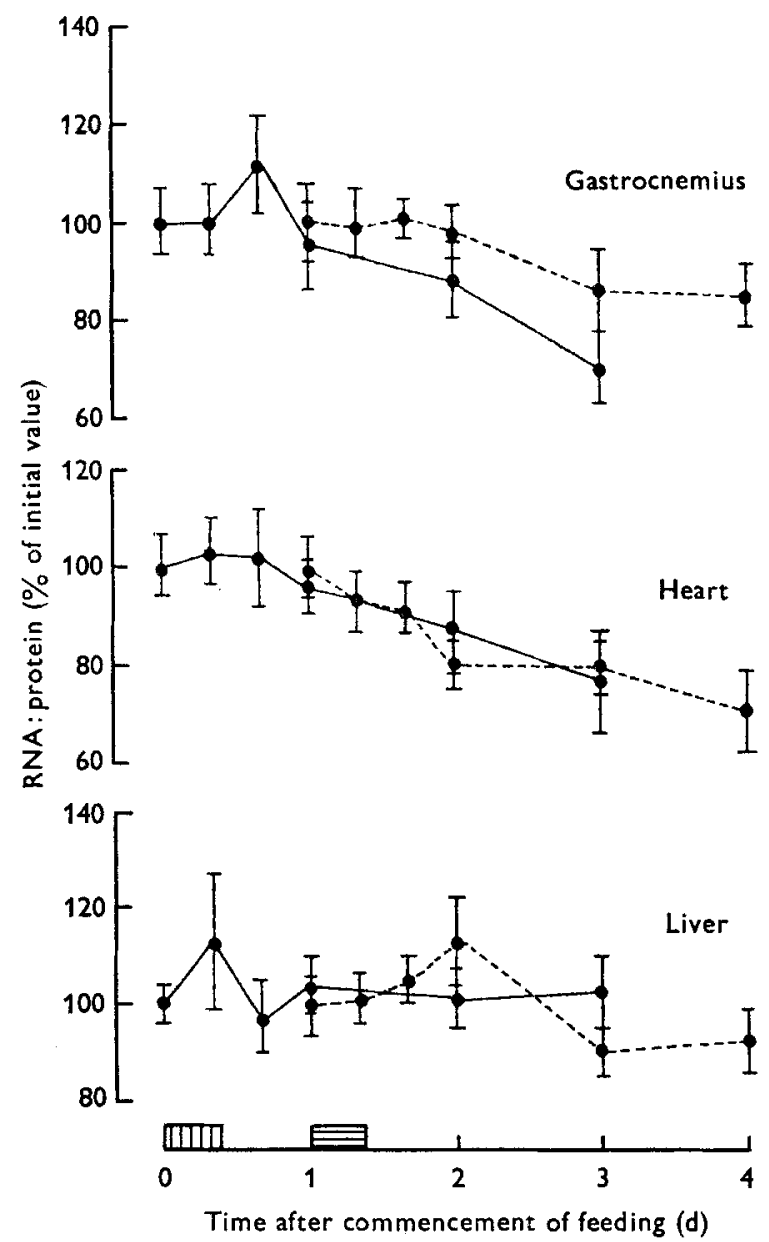

Fig. 6. Effect of $4+20$ feeding schedule (Watanabe, Potter \& Pitot, 1968) in Expts 2 and 4 on tissue RNA:protein ratios. -, Measurements made on rats given stock diet at beginning of the Ist day and subsequently fasted; -...., measurements made on rats given the protein-free diet at the beginning of the and day and subsequently fasted (mean values, and standard deviations represented by vertical bars); [D, stock diet feeding time; $\boxminus$, protein-free feeding time.

In gastrocnemius muscle the changes broadly reflected the changes in RNA:DNA ratios although they were not so pronounced. Thus, after feeding, the RNA:protein ratios rose $(0.05>P>0.025)$. There was little change in those of the heart muscle during this time. During fasting, however, the RNA:protein ratio fell in both heart and gastrocnemius muscle. In liver, on the other hand, the RNA:protein ratio reflected the RNA:DNA ratio after feeding but during starvation there was no change, since RNA and protein were both lost at the same rate.

Free amino acids in muscle. The concentration of free amino acids was measured in the gastrocnemius muscle in Expt 3. Unfortunately, the method used was not sensitive enough for measuring tryptophan content and did not satisfactorily resolve histidine, lysine or proline. The concentrations of the amino acids measured at the 
Table 3. Amino acid content (umollg tissue) of gastrocnemius muscle at the beginning of experimental period 3

(Mean values and standard deviations for three analyses: each sample analysed was the pooled gastrocnemius muscles from two rats)

$\begin{array}{lcc} & \text { Mean } & \text { SD } \\ \text { Aspartate } & 1 \cdot 29 & 0.20 \\ \text { Threonine } & 0.91 & 0.15 \\ \text { Serine } & 2.14 & 0.29 \\ \text { Asparagine } & 0.34 & 0.08 \\ \text { Glutamate } & 2.15 & 0.50 \\ \text { Glutamine } & 7.17 & 0.75 \\ \text { Glycine } & 10.00 & 1 \cdot 15 \\ \text { Alanine } & 3.57 & 0.67 \\ \text { Valine } & 0.112 & 0.011 \\ \text { Methionine } & 0.016 & 0.007 \\ \text { Isoleucine } & 0.110 & 0.018 \\ \text { Leucine } & 0.107 & 0.021 \\ \text { Tyrosine } & 0.271 & 0.028 \\ \text { Phenylaianine } & 0.077 & 0.014 \\ \text { Lysine } & 1.26 & 0.09 \\ \text { Arginine } & 0.39 & 0.05\end{array}$

beginning of the experiment are shown in Table 3. Fig. 7 shows the changes obtained in concentrations. While in some instances the changes following feeding were small, there were nevertheless increases of more than ro \% in the amounts of all amino acids except that of serine, which was unchanged, and glutamate and glycine contents, which fell. Threonine, aspartate, alanine, phenylalanine, leucine and valine increased by over $25 \%$, and methionine increased threefold. During the fasting period, however, there were more dramatic changes. As previously shown by Adibi (1971), the concentration of the essential amino acids increased. Isoleucine, leucine and methionine increased to $400-500 \%$ of the initial level after the $2 \mathrm{~d}$ fast, while valine, phenylalanine, tyrosine and arginine increased by $50 \%$. In each instance, these changes were greater than those which occurred after the feeding period. The response of the non-essential amino acids to fasting was more variable. The concentrations of alanine, serine, glycine and glutamine all fell by $10-50 \%$, threonine and glutamate were unchanged, and the concentrations of aspartate and asparagine increased by about $40 \%$.

The effect of feeding the protein-free diet and subsequent fasting. In Expt 4 a proteinfree diet was substituted for the stock diet in the final meal period. The stomach weights of these rats were not determined at death, but the body-weights of those rats killed $8 \mathrm{~h}$ after the commencement of feeding had increased by amounts similar to those of the rats given the stock diet, indicating that their food intakes had been similar. The results of Expt 4 have been presented in Figs 3, 4, 5, 6 and 7 so that the period of feeding with the protein-free diet corresponded to the beginning of the first fasting day in Expt 2. In this way the effectiveness of the protein-free diet in preventing the changes resulting from fasting can be compared direct.

Plasma insulin. The period of feeding with the protein-free diet had only a slight effect on plasma insulin levels. Fig. 3 shows that during the meal periods the insulin 


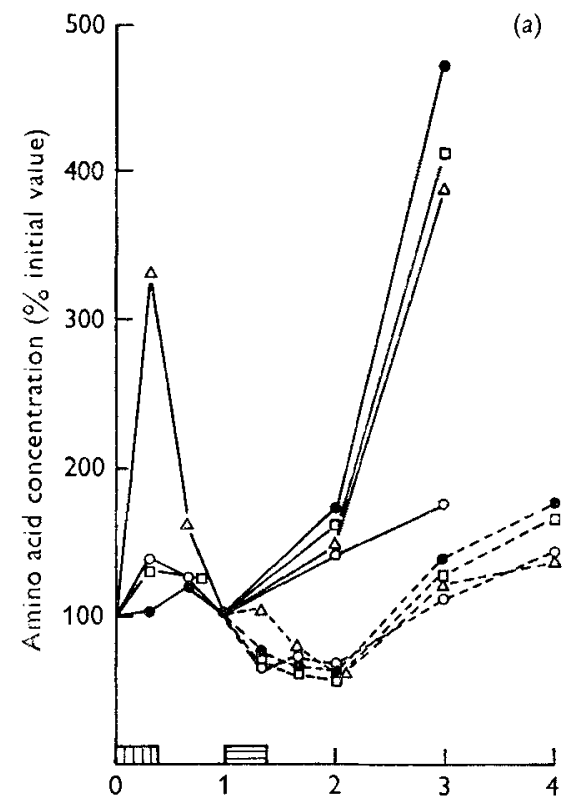

Time after commencement of feeding (d)

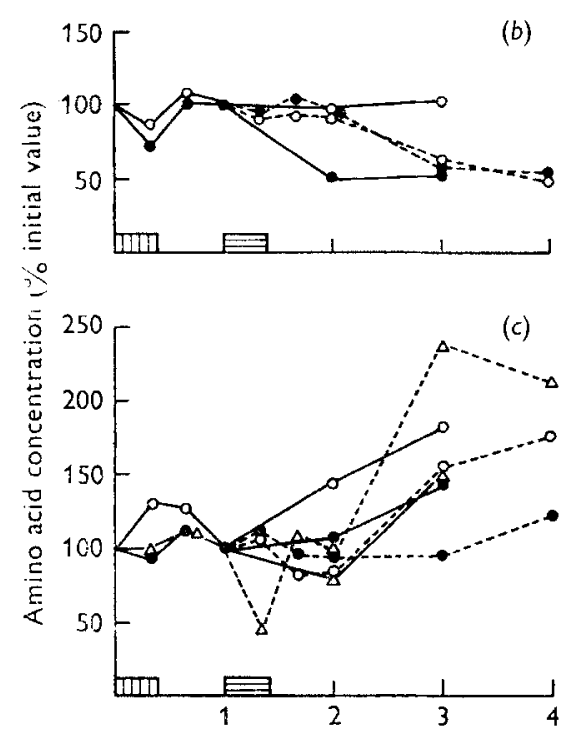

Time after commencement of feeding (d)

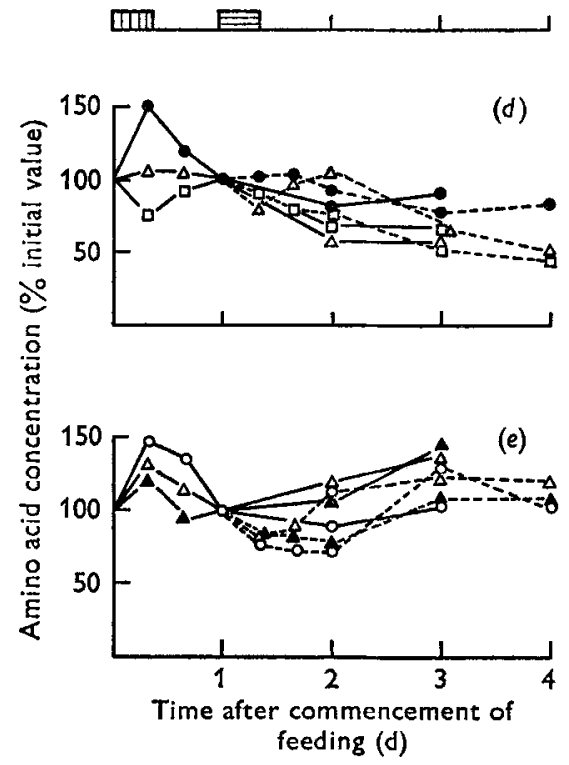

Fig. 7. Effect of $4+20$ feeding schedule (Watanabe, Potter \& Pitot, 1968) in Expts 3 and 4 on free amino acid concentrations of gastrocnemius muscle. -, (Expt 3) measurements made on rats given the stock diet at the beginning of the Ist day and subsequently fasted; ---, (Expt 4) measurements made on rats given the protein-free diet at the beginning of the and day and subsequently fasted; $\square$, stock diet feeding time; $⿴ 囗 ⿱ 一 一)$, protein-free diet feeding time. (a) $\bullet$, isoleucine; $O$, valine; $\square$, leucine; $\triangle$, methionine; $(b) 0$, glutamate; $O$, glutamine; (c) $O$, phenylalanine; $\Theta$, tyrosine; $\triangle$, arginine; $(d) \bullet$, alanine; $\square$, glycine; $\triangle$, serine; (e) $O$, threonine; $\Delta$, aspartate, $\boldsymbol{\Delta}$, asparagine. 
level increased from 20 to $29 \mu \mathrm{units} / \mathrm{ml}(0 . \mathrm{I}>P>0.05)$, but after this time the concentration fell to low levels comparable with those found in Expt 2.

Protein:DNA. The protein-free-diet feeding period induced a decrease in the protein: DNA ratio in all three tissues during the first $24 \mathrm{~h}$ (Fig. 4). In gastrocnemius muscle and heart, however, the effect was small ( 15 and $10 \%$ respectively) and the level of significance low $(0.025>P>0.0125)$. In the liver, however, the ratio fell by over $30 \%$ in the first $24 \mathrm{~h}(P<0.00 \mathrm{I})$ but after this time there was no change.

$R N A: D N A$. The RNA concentrations, expressed as RNA:DNA ratios in Fig. 5, decreased in all three tissues at rates similar to those found in corresponding period (i.e. the 2nd day) in Expt 2.

Because of the differences in the relative rates of loss of protein and RNA following the protein-free diet feeding period, the changes in the RNA:protein ratio (Fig. 7) in the three tissues were more variable. However, $3 \mathrm{~d}$ after this feeding period the RNA: protein ratio was lower than the initial value in both heart $(30 \%)$ and skeletal muscle ( $15 \%)$, while in liver the change was not significant.

Free amino acids. The free amino acid concentrations in gastrocnemius muscle responded to the protein-free diet feeding period as shown in Fig. 7. The amounts of branched-chain amino acids and methionine fell to $60-70 \%$ of the initial concentrations within the first $24 \mathrm{~h}$ of the feeding schedule. After this time, however, the concentrations increased as in Expt 2, although the increases were not as great. The other essential amino acids measured, arginine, phenylalanine and tyrosine, followed a similar pattern, although the changes in tyrosine concentrations were small. The amounts of glutamate, glutamine, alanine and serine changed little during the first $24 \mathrm{~h}$ period but decreased after this time, while those of aspartate, asparagine and threonine decreased initially but subsequently increased to the original levels or slightly higher levels.

\section{DISCUSSION}

The significance of changes in RNA concentrations: The relationship between muscle RNA content and the rate of protein synthesis can be described under two general headings (Millward et al. 1973). The efficiency of protein synthesis relates to the rate of peptide bond formation per unit of translational apparatus (e.g. per ribosome), whilst the capacity for protein synthesis reflects the amount of the translational apparatus present (e.g. the number of ribosomes or the total RNA). Although this is a simplified approach, it has been shown to be useful in describing the changes in the rate of protein synthesis in rat skeletal muscle when the diet is changed (Millward et al. 1973). In chronic protein deprivation the decreased capacity for protein synthesis is quantitatively more important than the fall in efficiency. The importance of changes in the capacity for protein synthesis in response to acute dietary manipulation will depend on the rate at which the concentration of tissue RNA can change. The results presented in this paper show that changes in the concentration of RNA in liver, heart and skeletal muscle are rapid, and increases can be measured after a single meal.

In other experiments we have measured the rate of synthesis of liver and muscle proteins in rats on a similar feeding schedule (Garlick, Millward \& James, 1973). 
After feeding there was an increase in the rate of muscle protein synthesis, at a time corresponding to the peak concentration of RNA reported here. Similarly Rebolledo \& Gagliardino (197I) have reported a circadian variation in the uptake of labelled leucine into mouse diaphragm protein. It is therefore likely that changes in the concentration of RNA in skeletal muscle are important factors in the short-term changes in muscle protein synthesis.

The rate of change of tissue RNA concentration is an indication of the turnover rate of RNA in these tissues. As the rate of change of mass is governed by the rates of synthesis and breakdown, the rapid changes in concentration of RNA reported here indicate rapid RNA turnover. For example, in Expt 2, the RNA:DNA ratio in gastrocnemius muscle increased by $18 \%$ and then fell to its original value during one $24 \mathrm{~h}$ feeding cycle. This means that the minimum rate of turnover of muscle RNA must have been $\mathrm{I} 8 \% / \mathrm{d}$ (i.e. a half-life of $3.8 \mathrm{~d}$ ). In liver, the minimum turnover rate is very similar, as the change in the RNA:DNA ratio following feeding was $20 \%$. In heart the changes were not as pronounced, indicating a minimum turnover rate of $10 \% / \mathrm{d}$ (equal to a half-life of ro d). It must be pointed out that the real rate of turnover could be considerably faster than these minimum rates.

The most widely used method for measuring RNA turnover has been the pulselabelling of RNA with radioactive orotic acid and the subsequent following of the decay rate. With this method, a half-life of $4 \mathrm{~d}$ has been reported for the liver (e.g. Enwonwu \& Munro, 1970). In skeletal muscle, however, using isotopic methods a relatively slow turnover rate was observed (Gerber, Gerber \& Altman, 1960). A possible explanation for the discrepancy between this report and the present findings is that reutilization of labelled nucleotides could result in a falsely high value for the half-life. Certainly when labelled orotic acid is used, reutilization has been demonstrated (Blobel \& Potter, 1968). The problems of reutilization are very similar to those found when labelled amino acids are used to study protein turnover (Millward, I970a).

The changes in RNA concentration observed in the present experiments can result from alterations in the rates of synthesis or breakdown. Munro (1968) has suggested that the increase in liver RNA after feeding is caused by the protection of ribosomal RNA from ribonuclease activity by polysome formation, itself a result of the influx of amino acids from the diet. As a result the rate of breakdown decreases and the amount of RNA increases.

The mechanism of the loss of RNA from the liver of fasted rats has also been investigated. Hirsch \& Hiatt (I966) reported an increase in the rate of RNA degradation in starved rats. More recently Enwonwu, Stambaugh \& Sreebny (I97I) reported a fivefold increase in the rate of breakdown, coincident with a smaller increase in the rate of synthesis of liver ribosomal RNA in fasted rats. It seems, therefore, from these studies that RNA concentrations in the liver are primarily controlled by changes in the rate of breakdown. Because of the similarity of the responses of muscle and liver RNA concentrations to feeding and fasting reported here, it is tempting to suggest a similar mechanism for the changes in RNA concentrations in muscle. We are at present investigating this problem. 
Free amino acid concentrations. Changes in the concentrations of intracellular amino acids have generally been thought to influence protein synthesis through a variety of mechanisms. It has been suggested that they play important roles in $(a)$ controlling RNA synthesis by affecting the level of at least one of the DNA-dependent RNA polymerases (Henderson, I972), (b) controlling RNA breakdown by maintaining ribosomal aggregation and hence resistance to ribonuclease (Munro, 1968), (c) controlling the rate of protein synthesis at the level of initiation (Morgan et al. I97I), elongation (Clemens \& Korner, 1971) and termination (Brunschede \& Bremer, 1971). In our experiments there were increases in most of the free amino acids of muscle following feeding which correspond to increases in RNA and in the rate of protein synthesis (Garlick et al. 1973). As starvation progressed, however, the concentrations of all essential amino acids measured increased to a greater extent than observed after feeding. This was particularly true of methionine and the branched-chain amino acids, which were increased several-fold at a time when RNA was being lost and when, presumably, protein synthesis was declining, as shown in other experiments (Millward, 1970b; Garlick et al. 1973). It therefore seems unlikely that the concentration of amino acids can be directly involved in the loss of RNA or the decrease in protein synthesis which occurs in starvation. The possible involvement of one of the essential amino acids not measured (e.g. tryptophan) cannot, however, be ruled out.

The tissue concentrations of free amino acids reflect the balance between rates of oxidation, rates of exchange with the plasma and net movement into or out of the protein pool. In starvation the only source of free amino acids is from protein breakdown. The liberation of free amino acids by net protein breakdown which occurs in starvation does not necessarily result in dramatic increases in free amino acid concentrations. Since the $\mathrm{K}_{m}$ for most of the transaminases is very much higher than the concentrations of the free amino acids in the tissues, amino acids can be very rapidly deaminated and channelled into catabolic pathways (Krebs, 1972). Nevertheless, the dramatic increase in the concentrations of methionine and the branched-chain amino acids during starvation is not entirely unexpected. If the concentrations of amino acids in gastrocnemius muscle protein reported by Adibi (1971) are compared with the concentrations of free amino acids in muscle in Table 2, then the protein-bound amino acid: free amino acid ratios are $2000,850,54^{\circ}$ and 290 for methionine, leucine, valine and isoleucine respectively. In contrast, the ratios for glycine, glutamate and glutamine, and alanine are 10,16 and $3^{\mathrm{I}}$ respectively.

There is consequently a disproportionate entry into the free amino acid pool of methionine and the branched-chain amino acids during net protein breakdown. It is also possible that the branched-chain amino acids liberated by net protein breakdown in other tissues, such as liver, may be deaminated in muscle, as the concentration of the transaminases for these amino acids is high in muscle (Ichihara \& Koyama, I966). Bloxam (1972) has reported that the branched-chain amino acids efflux from perfused liver under all conditions investigated.

The decrease in the concentrations of several of the non-essential amino acids is most probably due to their oxidation for energy supply. Alanine and glutamine, which are each involved in the transport of nitrogen from muscle to the liver and kidneys 
(Felig, Pozefsky, Marliss \& Cahill, I970; Marliss, Aoki, Pozefsky, Most \& Cahill, 197I) both decreased in concentration during the starvation period.

The fall in concentration of alanine may be related to the decrease in the rate of efflux of alanine from muscle reported by Felig et al. (1970) as fasting proceeds. Without direct measurements of flux rates, however, it is difficult to determine the cause of these changes.

Changes in insulin concentration. Insulin is the main factor in fuel control in animals (Weber, 1972). It is also of paramount importance in regulating protein metabolism and consequent inter-tissue amino acid movement (Manchester, 1970a), and Cahill (197I) has proposed that in evolutionary terms this was the original role of the hormone. In diaphragm muscle (Manchester, 1970b) and isolated chick embryo heart cells (Guidotti, I972), insulin promotes the uptake of those amino acids transported by the alanine-preferring site (Oxender $\&$ Christensen, 1963), in addition to its function in modulating protein synthesis by affecting ribosome function (Wool, 1972).

In our studies, the changes in muscle RNA expressed as RNA:DNA paralleled the changes in plasma insulin. Both amino acids (Munro, 1968) and insulin (Jefferson, Koehler \& Morgan, 1972) have been shown to affect the aggregation of ribosomes (and perhaps their concentration, as discussed above). It is possible, therefore, that the high insulin level following the meal period found in the present experiments may have had a double effect on the RNA concentration, one acting through the change in some amino acid levels, and another involving the direct interaction of insulin (or more precisely its second message (Wool, 1972)) with the ribosomes. In the fasting state, however, the concentrations of the essential amino acids were higher than those found during feeding, although the RNA concentration was decreasing. This indicates that the direct action of insulin on the ribosome is more important than its effect on amino acid transport.

The parallel changes in insulin and RNA concentration reported here may reflect the hormone's function in RNA synthesis. Weber (1972) has discussed the effects of insulin on hepatic enzyme induction and it has been reported that hepatic RNApolymerase activity is increased by this hormone (Steiner \& King, r966). A stimulatory effect of insulin on nucleic acid synthesis in muscle has also been reported (Wool, 1963), but other workers have not been able to demonstrate any effect in vitro (Manchester, 1967).

The protein-free diet. The protein-free diet was given, in these experiments, to assess the effectiveness of an input of energy in preventing the losses of RNA induced by starvation. As RNA was lost from all three tissues within the $24 \mathrm{~h}$ cycle after the protein-free meal, this diet was ineffective. The insulin responses were much less than those following the meal of the stock diet. A comparison of the concentrations of plasma insulin after the stock diet was given (Fig. 3) with the tissue RNA:DNA concentration (Fig. 6) shows that tissue RNA concentrations were falling when the plasma insulin was $40 \mu \mathrm{units} / \mathrm{ml}$ or less. As the plasma insulin concentration rose to only $25 \mu \mathrm{units} / \mathrm{ml}$ after feeding the protein-free diet it could be supposed that there is a minimum level of plasma insulin required to maintain RNA concentrations in the tissues. In these experiments the concentration seemed to be between 40 and $55 \mu$ units/ 
$\mathrm{ml}$. Nevertheless it is likely that the protein-free meal did have some effect on protein synthesis in muscle as the concentration of the branched-chain amino acids and methionine fell after the protein-free diet was fed. This suggests that for the $24 \mathrm{~h}$ period following the protein-free diet amino acid supply was, to some extent at least, rate limiting. However, the increase found in the concentration of these amino acids after $24 \mathrm{~h}$ suggests that other factors became more rate limiting in protein synthesis.

In the work presented here no dynamic measurements have been made. Nevertheless, the results demonstrate important factors in the general problem of the control of tissue protein synthesis. The concentration of muscle RNA and hence the capacity for protein synthesis can and does respond rapidly to alterations in the dietary intake in this tissue, and these changes parallel changes in the rate of protein synthesis measured in other experiments (e.g. Millward, r970b; Garlick et al. 1973). The problem of the relationship of plasma insulin, intracellular amino acids and RNA concentrations in skeletal muscle has been considered and the results indicate that, while changes in RNA concentration seem to reflect the concentrations of plasma insulin, they do not reflect changes in the concentrations of amino acids. However, methionine and the branched-chain amino acids which are present in disproportionately small concentrations seem to be very sensitive indicators of the status of protein synthesis in muscle.

The authors thank Mr P. Broadbent for the amino acid analyses, Dr C. Heard for the insulin assays, and Professor J. C. Waterlow for discussion of the manuscript. D.J.M. and P.J.G. would like to thank the MRC for financial support.

\section{REFERENCES}

Adibi, S. A. (1971). Am. F. Physiol. 221, 829.

Benson, J. V., Gordon, M. J. \& Patterson, J. A. (1967). Analyt. Biochem. 18, 228.

Blobel, G. \& Potter, V. R. (1968). Biochim. biophys. Acta 166, 48.

Bloxam, D. L. (1972). Br. F. Nutr. 27, 233.

Brunschede, H. \& Bremer, H. (1971). F. mol. Biol. 57, 35.

Cahill, G. F. Jr (r97r). Diabetes 20, 785 .

Clemens, M. J. \& Korner, A. (1971). Nature New Biol. 232, 252.

Enwonwu, C. O. \& Munro, H. N. (1970). Archs Biochem. Biophys. 138, 523.

Enwonwu, C. O., Stambaugh, R. \& Sreebny, L. (r97r). I. Nutr. ror, 337.

Felig, P., Pozefsky, T., Marliss, E. \& Cahill, G. F. Jr (1970). Science, N.Y. 167, 1003.

Garlick, P. J., Millward, D. J. \& James, W. P. T. (1973). Biochem. J. 136, 935.

Gerber, G., Gerber, G. \& Altman, K. I. (1960). F. biol. Chem. 235, 2682.

Giles, K. W. \& Meyers, A. (1965). Nature, Lond. 206, 93.

Guidotti, G. G. (1972). Proc. Nutr. Soc. 31, 79.

Hales, C. N. \& Randle, P. J. (1963). Biochem. Э. 88, 137.

Henderson, A. R. (1972). Proc. Nutr. Soc. 31, 29r.

Hirsch, C. A. \& Hiatt, H. H. (I g66). \%. biol. Chem. 24r, 5936.

Ichihara, A. \& Koyama, E. (1966). F. Biochem., Tokyo 59, r6o.

Jefferson, L. S., Koehler, J. O. \& Morgan, H. E. (r972). Proc. natn. Acad. Sci. U.S.A. 69, 8r6.

Krebs, H. A. (1972). In Advances in Enzyme Regulation Vol. 10, p. 397 [G. Weber, editor]. Oxford: Pergamon Press.

Lowry, O. H., Rosebrough, N. J., Farr, A. L. \& Randall, R. J. (195r). F. biol. Chem. 193, 265.

Manchester, K. L. (1967). Biochem. $\mathcal{F}$. 105, I3 C.

Manchester, K. L. (1970a). Biochem. F. II7, 457.

Manchester, K. L. (1970b). In Mammalian Protein Metabolism Vol. 4, Ch. 33 [H. N. Munro, editor]. New York and London: Academic Press.

Marliss, E. B., Aoki, T. T., Pozefsky, T., Most, A. S. \& Cahill, G. F. (I97 I). J. clin. Invest. 50, 8I4. 
Millward, D. J. (1970a). Clin. Sci. 39, 577.

Millward, D. J. (r97ob). Clin. Sci. 39, 59r.

Millward, D. J. \& Garlick, P. J. (1972). Proc. Nutr. Soc. 31, 257.

Millward, D. J., Garlick, P. J., James, W. P. T., Nnanyelugo, D. O. \& Ryatt, J. S. (1973). Nature, Lond. 241, 204.

Morgan, H. E., Jefferson, L. S., Wolpert, E. B. \& Rannels, D. E. (197I). F. biol. Chem. 246, 2 I63.

Munro, H. N. (1968). Fedn Proc, Fedn Am. Socs exp. Biol. 27, 1231.

Munro, H. N. \& Fleck, A. (1969). In Mammalian Protein Metabolism Vol. 3, p. 423 [H. N. Munto, editor]. New York and London: Academic Press.

Oxender, D. L. \& Christensen, H. N. (1963), f. biol. Chem. 238, 3686.

Payne, P. R. \& Stewart, R. J. C. (1972). Lab. Anim. 6, 135.

Potter, V. R., Baril, E. F., Watanabe, M. \& Whittle, E. D. (1968). Fedn Proc. Fedn Am. Socs exp. Biol. 27,1238 .

Rebolledo, O. R. \& Gagliardino, J. J. (1971). F. Interdiscip. Cycle Res, 2, ror.

Steiner, D. F. \& King, J. (1966). Biochim. biophys. Acta rr9, 510.

Watanabe, M., Potter, V. R. \& Pitot, H. C. (1968). F. Nutr. 95, 207.

Waterlow, J. C. \& Stephen, J. M. L. (rg68). Clin. Sci. 35, 287.

Weber, G. (1972). Israel \%. med. Sci. 8, 325.

Wool, I. G. (1963). Biochim. biophys. Acta 68, 28.

Wool, I. G. (1972). Proc. Nutr. Soc. 3r, 185.

Young, V.R. (1970). In Mammalian Protein Metabolism Vol. 4, Ch. 40 [H. N. Munro, editor]. New York and London: Academic Press. 